\title{
A novel and practical asymmetric synthesis of dapoxetine hydrochloride
}

\author{
Yijun Zhu ${ }^{1,2}$, Zhenren Liu ${ }^{1}$, Hongyan $\mathrm{Li}^{1}$, Deyong Ye ${ }^{* 2}$ and Weicheng Zhou ${ }^{* 1}$
}

\author{
Full Research Paper \\ Address: \\ ${ }^{1}$ State Key Lab of New Drug \& Pharmaceutical Process, Shanghai \\ Key Lab of Anti-Infectives, State Institute of Pharmaceutical Industry, \\ No. 285, Gebaini Rd., Shanghai 201203, China and ${ }^{2}$ School of \\ Pharmacy, Fudan University, No. 826, Zhangheng Rd., Shanghai \\ 201203, China \\ Email: \\ Deyong Ye* - dyye@shmu.edu.cn; Weicheng Zhou* - \\ zhouweicheng58@163.com \\ * Corresponding author

\section{Keywords:} \\ asymmetric synthesis; dapoxetine hydrochloride; stereoselectivity; \\ (S)-tert-butanesulfinamide \\ Beilstein J. Org. Chem. 2015, 11, 2641-2645. \\ doi:10.3762/bjoc. 11.283 \\ Received: 27 July 2015 \\ Accepted: 10 December 2015 \\ Published: 17 December 2015 \\ Associate Editor: D. Dixon \\ (c) 2015 Zhu et al; licensee Beilstein-Institut. \\ License and terms: see end of document.
}

\section{Abstract}

A novel and practical asymmetric synthesis of dapoxetine hydrochloride by using the chiral auxiliary $(S)$-tert-butanesulfinamide was explored. The synthesis was concise, mild, and easy to perform. The overall yield and stereoselectivity were excellent.

\section{Introduction}

Premature ejaculation (PE) is the most frequent form of ejaculatory dysfunction with a distribution of $39 \%$ of the general male population $[1,2]$. Dapoxetine hydrochloride $(\mathbf{1},(S)-(+)-N, N-$ dimethyl-[3-(naphthalen-1-yloxy)-1-phenylpropyl]amine hydrochloride, Figure 1) was approved by EMA in 2009 for the special treatment of PE $[3,4]$. By virtue of its fast acting property and rapid elimination from the body, it is one of the more effective and safe drugs for treating PE.

For this reason, the synthesis of this interesting drug has attracted great attention, especially asymmetric synthesis approaches. However, only a few methods have been reported for the synthesis of enantiopure dapoxetine hydrochloride. The earlier methods included chiral/enzymatic resolution [5],

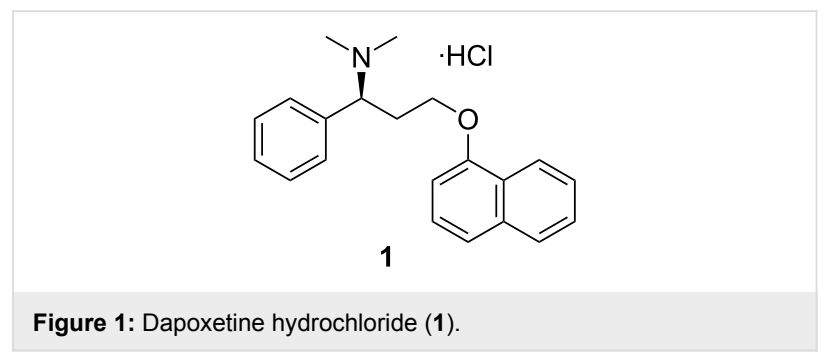

whereas the newer approaches encompass asymmetric dihydroxylation of trans-methyl cinnamate or cinnamyl alcohol [6], chiral azetidin-2,3-dione [7], asymmetric $\mathrm{C}-\mathrm{H}$ amination reactions of a prochiral sulfamate [8], oxazaborolidine reduction of 3-chloropropiophenone or ketone [9], and an imidazolidin-2- 
one chiral auxiliary mediated acetate aldol reaction [10]. However, these methods are undermined by poor yield, low enantioselectivity, and complex synthetic procedure.

Chiral tert-butanesulfinamide, developed by García Ruano and Ellman, has been proven to be a broadly useful reagent for the preparation of chiral amines via the chiral $N$-tert-butanesulfinylimine intermediates $[11,12]$. Due to its high diastereoselectivity and convenient cleavage of the $\mathrm{N}$-tert-butanesulfinyl group, it has become an excellent chiral auxiliary in the synthesis of chiral amine compounds [13]. This work was devoted to develop an efficient synthetic route for the synthesis of $(S)$ dapoxetine (1) through this chiral auxiliary.

\section{Results and Discussion}

Herein, a novel and practical synthesis of $\mathbf{1}$ (Scheme 1) based on (S)-tert-butanesulfinamide (2) was developed.
3-(Naphthalen-1-yloxy)-1-phenylpropan-1-one (3), which was commercially available from J\&K Chemical Ltd., was chosen as a key building block to be condensed with $\mathbf{2}$ to form the imine. The reaction in the presence of $\mathrm{Ti}(\mathrm{OEt})_{4}$ gave compound 4 in $78 \%$ yield [14] (Scheme 1).

The diastereoselective reduction of imine 4 (Scheme 2) was the key step in this route. Accordingly, various conditions were screened and the results are presented in Table 1.

Following a procedure reported in the literature [14], the reduction of 4 was carried out with $\mathrm{NaBH}_{4}$ in THF at $25{ }^{\circ} \mathrm{C}$ for $1 \mathrm{~h}$ (Table 1, entry 1 ). However, the main product was proven to be the denaphthalenyloxy compound 5', by ${ }^{1} \mathrm{H}$ NMR and MS while the desired sulfinamide $\mathbf{5}$ was obtained only in a yield of $28 \%$. The amount of denaphthalenyloxy was greatly reduced when the reaction temperature was decreased to $-30{ }^{\circ} \mathrm{C}$

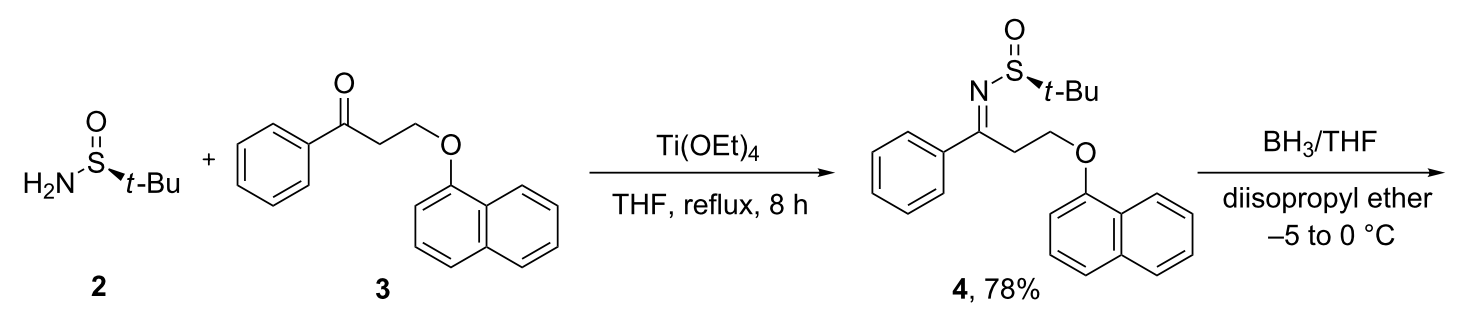<smiles>CC(C)(C)C(=O)N[C@H](CCOc1cccc2ccccc12)c1ccccc1</smiles>

1) $28 \% \mathrm{HCl} / \mathrm{EtOH}$ $\mathrm{CH}_{3} \mathrm{OH}, 10$ to $20^{\circ} \mathrm{C}$

2) $\mathrm{NaHCO}_{3}(\mathrm{aq}), \mathrm{DCM}$<smiles>NC(CCCc1cccc2ccccc12)c1ccccc1</smiles>

6, $90 \%$ 5, $79 \%$<smiles>CN(C)C(CCOc1cccc2ccccc12)c1ccccc1</smiles>

$7,75 \%$

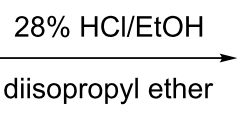<smiles>CN(C)[C@H](CCOc1cccc2ccccc12)c1ccccc1</smiles>

$1,80 \%$

ee $>99 \%$

Scheme 1: Asymmetric synthesis of 1.<smiles>CC(C)(C)[As](=O)/N=C(\CCOc1cccc2ccccc12)c1ccccc1</smiles>

Scheme 2: Reduction of sulfinylimine 4.<smiles>CC(C)(C)S(=O)N[C@@H](CCOc1cccc2ccccc12)c1ccccc1</smiles><smiles>CC(C)(C)C(=O)N[C@@H](CCOc1cccc2ccccc12)c1ccccc1</smiles>

5'<smiles>CCCCCS(=O)NC(CC)c1ccccc1</smiles> 
Table 1: Conditions for the reduction of sulfinylimine 4.

\begin{tabular}{|c|c|c|c|c|c|c|}
\hline entry & reductant & solvent & $T\left({ }^{\circ} \mathrm{C}\right)$ & time $(\mathrm{h})$ & crude product $\left(5: 5^{\prime}: 5^{\prime \prime}\right)$ & $\mathrm{de}^{\mathrm{a}}(\%)$ \\
\hline 1 & $\mathrm{NaBH}_{4}(0.8$ equiv $)$ & THF & 25 & 1 & $28 \%: 9 \%: 62 \%$ & 51 \\
\hline 2 & $\mathrm{NaBH}_{4}(0.8$ equiv $)$ & THF & -30 & 3 & 56\%:11\%:33\% & 67 \\
\hline 3 & $\mathrm{NaBH}_{4}(0.8$ equiv $)$ & THF & -70 & 4 & $60 \%: 12 \%: 28 \%$ & 67 \\
\hline $4^{b}$ & $\mathrm{NaBH}_{4}(0.8$ equiv $)$ & THF & 25 & 2 & 67\%:22\%:11\% & 61 \\
\hline $5^{b}$ & $\mathrm{NaBH}_{4}$ (0.8 equiv) & THF & -30 & 2.5 & 70\%:21\%:2\% & 54 \\
\hline 6 & $\mathrm{NaBH}_{3} \mathrm{CN}$ ( 1 equiv) & THF & -20 & 2 & $\mathrm{ND}^{\mathrm{C}}$ & \\
\hline 7 & $\mathrm{BH}_{3}$ (1 equiv) & THF & -20 & 2 & $82 \%: 14 \%: 4 \%$ & 71 \\
\hline 8 & $\mathrm{BH}_{3}$ (0.8 equiv) & THF & -20 & 2 & $81 \%: 13 \%: 6 \%$ & 72 \\
\hline 9 & $\mathrm{BH}_{3}$ (0.6 equiv) & THF & -20 & 6 & $76 \%: 14 \%: 6 \%$ & 69 \\
\hline 10 & $\mathrm{BH}_{3}$ (0.8 equiv) & THF & 0 & 1 & $81 \%: 17 \%: 2 \%$ & 66 \\
\hline 11 & $\mathrm{BH}_{3}$ (0.8 equiv) & THF & 25 & 0.5 & $81 \%: 15 \%: 4 \%$ & 69 \\
\hline 12 & $\mathrm{BH}_{3}$ (0.8 equiv) & MTBE & 25 & 1 & $80 \%: 11 \%: 9 \%$ & 76 \\
\hline 13 & $\mathrm{BH}_{3}$ (0.8 equiv) & 2-MeTHF & 25 & 1 & $80 \%: 16 \%: 4 \%$ & 67 \\
\hline 14 & $\mathrm{BH}_{3}$ (0.8 equiv) & IPE $^{d}$ & 25 & 1 & $85 \%: 10 \%: 4 \%$ & 78 \\
\hline 15 & $\mathrm{BH}_{3}$ (0.8 equiv) & IPE $^{d}$ & 0 & 1.5 & 87\%:5\%:1\% & 89 \\
\hline 16 & $\mathrm{BH}_{3}$ (0.8 equiv) & $\mathrm{IPE}^{\mathrm{d}}$ & -25 & 3 & e & 85 \\
\hline
\end{tabular}

aDiastereoisomeric excess of $\mathbf{5}$ and $\mathbf{5}$; ; badded $\mathrm{AcOH}$ (0.1 equiv) in the reaction; ${ }^{\circ}$ no products were detected; ${ }^{d}$ diisopropyl ether; e $5: 5$ ':4 55\%:4\%:40\%.

(Table 1, entry 2), but no significant improvement was achieved by further decreasing the temperature (Table 1 , entry 3 ). It was assumed that after reduction, the basicity resulting from $\mathrm{NaBH}_{4}$ might lead to the denaphthalenyloxylation. Therefore, $\mathrm{AcOH}$ was used as an additive in the reaction. The results showed that the denaphthalenyloxylation was almost negligible, but the diastereoselectivity was not good enough (Table 1, entry 5). Although mild reductant, $\mathrm{NaBH}_{3} \mathrm{CN}$, was then applied in the reaction, no reaction took place (Table 1 , entry 6). When $\mathrm{BH}_{3}$ was used to react with 4 at $-20{ }^{\circ} \mathrm{C}$ for $2 \mathrm{~h}$, the result was promising in terms of both yield and de (Table 1, entry 7 ). The data of entries 7-11 indicated that 0.8 equiv of the reductant $\mathrm{BH}_{3}$ was sufficient and the optimized temperature was $0-25{ }^{\circ} \mathrm{C}$ when the reaction was carried out in THF. When other solvents were tested (Table 1, entries 12-14), it was found that diisopropyl ether gave the best result. Finally, the reaction was performed with 0.8 equiv $\mathrm{BH}_{3}$ in isopropyl ether at $0{ }^{\circ} \mathrm{C}$ for $1.5 \mathrm{~h}$ (Table 1, entry 15) and the de of the crude product was $89 \%$. Compound 5 was isolated in pure form from the crude reaction mixture by recrystallization from $10 \%$ ethyl acetate/ $n$-heptane in $79.2 \%$ yield with $99.0 \%$ de.

Then purified 5 was hydrolyzed in methanol with $\mathrm{HCl} / \mathrm{EtOH}$ solution at room temperature and dissociated with $\mathrm{NaHCO}_{3}$ to give the primary amine 6 in $90.0 \%$ yield. The reductive amination of 6 under Eschweiler-Clarke conditions furnished $(S)$ dapoxetine 7 with excellent enantiopurity $(99.3 \%$ ee) in $74.7 \%$ yield. After salt formation and recrystallization, the target com- pound 1 was obtained. The optical rotation value of compound 1 was consistent with that previously reported [15], which confirmed that the $S$-enantiomer of dapoxetine hydrochloride was synthesized successfully by using this route.

\section{Conclusion}

In summary, a novel and stereoselective synthesis of dapoxetine hydrochloride starting from commercially available 3-(naphthalen-1-yloxy)-1-phenylpropan-1-one in five linear steps (33.5\% overall yield) via introduction of the chiral auxiliary $(S)$-tert-butanesulfinamide was developed. This method was easy to perform and both the purity and yield of the product were excellent.

\section{Experimental}

All solvents and reagents were of reagent grade and used without further purification. ${ }^{1} \mathrm{H}$ and ${ }^{13} \mathrm{C}$ NMR spectra were recorded using a Bruker $400 \mathrm{MHz}$ spectrometer with TMS as an internal standard. HPLC analyses were recorded with on a Dionex Ultimate 3000 chromatograph and chiral HPLC analyses were recorded with an Agilent 1100 Series spectrometer.

Preparation of $(S)-2-m e t h y l-N$-(3-(naphthalen-1-yloxy)-1phenylpropylidene)propane-2-sulfinamide (4): To a solution of $3(30 \mathrm{~g}, 0.11 \mathrm{~mol})$ and (S)-tert-butanesulfinamide (14.7 g, $0.12 \mathrm{~mol})$ in THF $(300 \mathrm{~mL}), \mathrm{Ti}(\mathrm{OEt})_{4}(61.8 \mathrm{~g}, 0.22 \mathrm{~mol})$ was added under $\mathrm{N}_{2}$ atmosphere and the mixture was refluxed at 
$65{ }^{\circ} \mathrm{C}$ for about $8 \mathrm{~h}$. Upon completion (as determined by TLC), the reaction mixture was first cooled to $\mathrm{rt}$ and then quenched with ethyl acetate $(300 \mathrm{~mL})$ and brine $(300 \mathrm{~mL})$, then stirred for $1 \mathrm{~h}$, filtered, and the filtrate was washed with brine and dried over $\mathrm{Na}_{2} \mathrm{SO}_{4}$ and concentrated. The residue was purified via flash chromatography with petrol ether/ethyl acetate $(20: 1)$ to give 4 as a pale yellow solid. Yield $32.3 \mathrm{~g}$ (78.3\%); mp $49-51{ }^{\circ} \mathrm{C} ;[\alpha]_{\mathrm{D}}^{25}-10\left(c 0.8, \mathrm{CDCl}_{3}\right) ;{ }^{1} \mathrm{H}$ NMR $(400 \mathrm{MHz}$, $\left.\mathrm{CDCl}_{3} / \mathrm{TMS}\right) \delta 8.10(\mathrm{~d}, J=8 \mathrm{~Hz}, 1 \mathrm{H}), 7.79(\mathrm{~d}, J=8 \mathrm{~Hz}, 1 \mathrm{H})$, $7.51-7.28(\mathrm{~m}, 8 \mathrm{H}), 6.81(\mathrm{~d}, J=7.6 \mathrm{~Hz}, 1 \mathrm{H}), 4.62-4.49(\mathrm{~m}, 2 \mathrm{H})$, 4.02-3.79 (m, 2H), $1.39(\mathrm{~s}, 9 \mathrm{H}) ;{ }^{13} \mathrm{C} \mathrm{NMR}\left(100 \mathrm{MHz}, \mathrm{CDCl}_{3} /\right.$ TMS) $\delta 197.7,154.4,137.0,134.6,133.3,128.7,128.2,127.4$, 126.3, 125.8, 125.7, 125.1, 122.0, 120.5, 105.0, 77.3, 77.0, 76.6, 63.9, 38.2; HRMS $\left(\mathrm{ES}^{+}\right) \mathrm{m} / z$ : $[\mathrm{M}+\mathrm{Na}]^{+}$calcd for $\mathrm{C}_{23} \mathrm{H}_{25} \mathrm{NO}_{2} \mathrm{NaS}$, 402.1504; found, 402.1493.

Preparation of (S)-2-methyl- $\mathrm{N}-((S)-3-($ naphthalen-1-yloxy)1-phenylpropyl)propane-2-sulfinamide (5): To a suspension of $4(20 \mathrm{~g}, 53 \mathrm{mmol})$ in diisopropyl ether $(300 \mathrm{~mL}), \mathrm{BH}_{3} / \mathrm{THF}$ $(10 \mathrm{~mL}, 42.2 \mathrm{mmol})$ was added dropwise at -5 to $0{ }^{\circ} \mathrm{C}$. After this addition, the reaction mixture was stirred for $1.5 \mathrm{~h}$. The color of the reaction changed from yellow to white and TLC showed the complete consumption of 4 . Then, ethyl acetate $(200 \mathrm{~mL})$ and water $(100 \mathrm{~mL})$ were added and the mixture was stirred for $5 \mathrm{~min}$ and then separated. The organic phase was washed with brine, dried over $\mathrm{Na}_{2} \mathrm{SO}_{4}$, and filtered and concentrated to obtain the crude product. The crude product was crystallized from an $n$-heptane/ethyl acetate mixture (9:1) to get pure 5 as an off-white solid. Yield $15.9 \mathrm{~g}$ (79.2\%); mp 60-61 ${ }^{\circ} \mathrm{C} ;[\alpha]_{\mathrm{D}}^{25} 65.8$ (c 1, $\left.\mathrm{CDCl}_{3}\right)$; de $99.0 \% ;{ }^{1} \mathrm{H} \mathrm{NMR}$ (400 MHz, $\left.\mathrm{CDCl}_{3} / \mathrm{TMS}\right) \delta 8.20(\mathrm{~d}, J=8.4 \mathrm{~Hz}, 1 \mathrm{H}), 7.79(\mathrm{~d}, J=$ $8.4 \mathrm{~Hz}, 1 \mathrm{H}), 7.51-7.28(\mathrm{~m}, 8 \mathrm{H}), 6.67(\mathrm{~d}, J=7.6 \mathrm{~Hz}, 1 \mathrm{H}), 4.80$ $(\mathrm{m}, 1 \mathrm{H}), 4.15(\mathrm{~m}, 1 \mathrm{H}), 4.02(\mathrm{~m}, 1 \mathrm{H}), 3.58(\mathrm{~d}, \mathrm{NH}), 2.66(\mathrm{~m}$, $1 \mathrm{H}), 2.35(\mathrm{~m}, 1 \mathrm{H}), 1.22(\mathrm{~s}, 9 \mathrm{H}) ;{ }^{13} \mathrm{C} \mathrm{NMR}\left(100 \mathrm{MHz}, \mathrm{CDCl}_{3} /\right.$ TMS) $\delta 154.5,141.9,134.6,128.9,128.1,127.4,127.2,126.4$, 125.7, 125.3, 122.0, 120.4, 104.6, 94.5, 77.3, 77.2, 77.0, 76.7, 64.7, 56.8, 55.9, 36.5, 22.6; HRMS $\left(\mathrm{ES}^{+}\right) \mathrm{m} / z:[\mathrm{M}+\mathrm{H}]^{+}$calcd for $\mathrm{C}_{23} \mathrm{H}_{28} \mathrm{NO}_{2} \mathrm{~S}, 382.1841$; found, 382.1842 .

Preparation of $(S)$-3-(naphthalen-1-yloxy)-1-phenylpropan1-amine (6): To a solution of 5 (12 g, $31.5 \mathrm{mmol})$ dissolved in methanol $(60 \mathrm{~mL}), 28 \% \mathrm{HCl} / \mathrm{EtOH}(9 \mathrm{~mL}, 63 \mathrm{mmol})$ was added at $10-20{ }^{\circ} \mathrm{C}$. The mixture was stirred for $1 \mathrm{~h}$ at room temperature. Then, the mixture was concentrated and the obtained crude residue was resuspended with MTBE $(70 \mathrm{~mL})$ to give pure hydrochloride 6. The solid was suspended in DCM $(50 \mathrm{~mL})$, and saturated aqueous $\mathrm{NaHCO}_{3}$ solution $(15 \mathrm{~mL})$ was added and stirred until the mixture was no longer turbid. The organic phase was washed with brine, dried over $\mathrm{Na}_{2} \mathrm{SO}_{4}$, and filtered and concentrated to give 6 as a pale yellow oil. Yield $7.4 \mathrm{~g}$ $(90.0 \%) ;[\alpha]_{\mathrm{D}}^{25} 66.1\left(c 0.3, \mathrm{CDCl}_{3}\right) ;{ }^{1} \mathrm{H} \mathrm{NMR}(400 \mathrm{MHz}$,
$\left.\mathrm{CDCl}_{3} / \mathrm{TMS}\right) \delta 8.26(\mathrm{~d}, J=8.4 \mathrm{~Hz}, 1 \mathrm{H}), 7.79(\mathrm{~d}, J=8.4 \mathrm{~Hz}$, $1 \mathrm{H}), 7.51-7.28(\mathrm{~m}, 8 \mathrm{H}), 6.75(\mathrm{~d}, 1 \mathrm{H}), 4.35(\mathrm{~m}, 1 \mathrm{H}), 4.23(\mathrm{~m}$, 1H), $4.11(\mathrm{~m}, 1 \mathrm{H}), 2.34(\mathrm{~m}, 2 \mathrm{H}) ;{ }^{13} \mathrm{C} \mathrm{NMR}\left(100 \mathrm{MHz}, \mathrm{CDCl}_{3} /\right.$ TMS) $\delta 154.6,145.0,134.6,128.7,127.4,127.4,126.4,126.3$, 125.8, 125.1, 122.0, 120.3, 104.8, 77.3, 77.0, 76.7, 65.5, 53.7, 38.5; $\mathrm{MS}\left(\mathrm{ES}^{+}\right) \mathrm{m} / z: 278[\mathrm{M}+\mathrm{H}]^{+}$.

\section{Preparation of dapoxetine ((S)- $\mathrm{N}, \mathrm{N}$-dimethyl-3-(naphthalen-} 1-yloxy)-1-phenylpropan-1-amine, 7): To a $50 \mathrm{~mL}$ roundbottomed flask, 6 (6 g, $21.6 \mathrm{mmol}), 98 \% \mathrm{HCOOH}(3.9 \mathrm{~mL}$, $54.1 \mathrm{mmol})$ and an aqueous solution of $30 \%$ formaldehyde $(9.7 \mathrm{~mL}, 108 \mathrm{mmol})$ were added at room temperature. The reaction mixture was heated to $85^{\circ} \mathrm{C}$ for $8 \mathrm{~h}$ and quenched with saturated aqueous $\mathrm{NaHCO}_{3}$ solution $(\mathrm{pH} \approx 8)$. The aqueous layer was extracted with EtOAc $(20 \mathrm{~mL}$, twice). The organic phase was washed with water, brine, dried over $\mathrm{Na}_{2} \mathrm{SO}_{4}$ and concentrated. The residue was purified by flash chromatography to afford dapoxetine as a colorless oil. Yield $4.95 \mathrm{~g}$ (74.7\%); chiral purity (HPLC): 99.63\%; ${ }^{1} \mathrm{H} \mathrm{NMR}(400 \mathrm{MHz}$, $\left.\mathrm{CDCl}_{3} / \mathrm{TMS}\right) \delta 8.26(\mathrm{~d}, J=9.2 \mathrm{~Hz}, 1 \mathrm{H}), 7.79(\mathrm{~d}, J=9.2 \mathrm{~Hz}$, $1 \mathrm{H}), 7.47(\mathrm{~m}, 2 \mathrm{H}), 7.35-7.28(\mathrm{~m}, 7 \mathrm{H}), 6.67(\mathrm{~d}, J=8 \mathrm{~Hz}, 1 \mathrm{H})$, 4.13-4.08 (m, 1H), 3.98-3.94 (m, 1H), 3.64-3.60 (m, 1H), 2.67-2.62 (m, 1H), 2.33-2.31 (m, 1H), $2.29(\mathrm{~s}, 6 \mathrm{H}) ;{ }^{13} \mathrm{C} \mathrm{NMR}$ (100 MHz, $\left.\mathrm{CDCl}_{3} / \mathrm{TMS}\right) \delta 154.7,134.5,128.6,128.2,127.4$, 126.3, 125.8, 125.0, 122.0, 120.1, 104.7, 77.3, 77.0, 76.6, 67.8, 65.7, 42.7, 33.0; $\mathrm{MS}\left(\mathrm{ES}^{+}\right) \mathrm{m} / z: 306[\mathrm{M}+\mathrm{H}]^{+}$.

Preparation of dapoxetine hydrochloride (1): To a solution of 7 ( $3 \mathrm{~g}, 9.8 \mathrm{mmol})$ dissolved in diisopropyl ether $(30 \mathrm{~mL})$, $28 \% \mathrm{HCl} / \mathrm{EtOH}$ (1.3 mL, 1.2 equiv) was added dropwise at room temperature. A white solid was precipitated and filtered to obtain the crude $\mathbf{1}$ ( $2.8 \mathrm{~g})$. The solid was recrystallized from isopropyl alcohol $/ n$-hexane $(9 \mathrm{~mL}: 8 \mathrm{~mL})$ to give the product. Yield $2.7 \mathrm{~g}(80.4 \%) ; \mathrm{mp} 178-180{ }^{\circ} \mathrm{C} ;[\alpha]_{\mathrm{D}}^{25} 126.4$ (c 1, methanol) [lit. [15] mp $180-184{ }^{\circ} \mathrm{C} ;[\alpha]_{\mathrm{D}}^{25} 131.7$ (c 1, methanol)]; chiral purity (HPLC): $>99 \%$ ee; ${ }^{1} \mathrm{H}$ NMR (400 MHz, DMSO- $\left.d_{6} / \mathrm{TMS}\right) \delta$ 11.21 (brs, $1 \mathrm{H}, \mathrm{HCl}), 8.06-6.73(\mathrm{~m}, 12 \mathrm{H}), 4.71(\mathrm{~m}, 1 \mathrm{H}), 4.11$ $(\mathrm{m}, 1 \mathrm{H}), 3.75(\mathrm{~m}, 1 \mathrm{H}), 2.95(\mathrm{~m}, 1 \mathrm{H}), 2.92(\mathrm{~s}, 3 \mathrm{H}), 2.73(\mathrm{~m}, 1 \mathrm{H})$, $2.58(\mathrm{~s}, 3 \mathrm{H}) ;{ }^{13} \mathrm{C}$ NMR $\left(100 \mathrm{MHz}, \mathrm{DMSO}-d_{6} / \mathrm{TMS}\right) \delta 153.7$, 134.0, 132.5, 129.9, 129.7, 129.0, 127.4, 126.5, 126.1, 125.2, $124.9,121.8,120.2,105.1,67.3,64.6,41.4,40.3,40.1,39.9$, 39.7, 39.5, 39.3, 39.0, 29.6; $\mathrm{MS}\left(\mathrm{ES}^{+}\right) \mathrm{m} / z: 306[\mathrm{M}+\mathrm{H}]^{+}$.

\section{Supporting Information}

\section{Supporting Information File 1}

${ }^{1} \mathrm{H}$ NMR, ${ }^{13} \mathrm{C}$ NMR and ESIMS spectra of compounds $\mathbf{1}$,

4, 5, 5”, 6 and 7 and chiral HPLC diagrams of 1 and 7.

[http://www.beilstein-journals.org/bjoc/content/

supplementary/1860-5397-11-283-S1.pdf] 


\section{References}

1. Althof, S. E. J. Urol. 2006, 175, 842-848. doi:10.1016/S0022-5347(05)00341-1

2. Zhou, C.; Jiang, X.; Xu, Z.; Guo, L.; Wang, H.; Zhang, D.; Shi, B. J. Sex. Med. 2010, 7, 3750-3757. doi:10.1111/j.1743-6109.2009.01646.x

3. Sorbera, L. A.; Castaner, J.; Castaner, R. M. Drugs Future 2004, 29, 1201-1205. doi:10.1358/dof.2004.029.12.865936

4. Darcsi, A.; Tóth, G.; Kökösi, J.; Béni, S. J. Pharm. Biomed. Anal. 2014, 96, 272-277. doi:10.1016/j.jpba.2014.04.002

5. Torre, O.; Gotor-Fernández, V.; Gotor, V. Tetrahedron: Asymmetry 2006, 17, 860-866. doi:10.1016/j.tetasy.2006.02.022

6. Siddiqui, S. A.; Srinivasan, K. V. Tetrahedron: Asymmetry 2007, 18, 2099-2103. doi:10.1016/j.tetasy.2007.07.028

7. Chincholkar, P. M.; Kale, A. S.; Gumaste, V. K.; Deshmukh, A. R. A. S Tetrahedron 2009, 65, 2605-2609. doi:10.1016/j.tet.2008.11.042

8. Kang, S.; Lee, H.-K. J. Org. Chem. 2010, 75, 237-240. doi:10.1021/jo902176s

9. Kim, S. J.; Jeon, T. H.; Min, I. S.; Kim, I. S.; Jung, Y. H. Tetrahedron Lett. 2012, 53, 3680-3682. doi:10.1016/j.tetlet.2012.05.037

10. Khatik, G. L.; Sharma, R.; Kumar, V.; Chouhan, M.; Nair, V. A. Tetrahedron Lett. 2013, 54, 5991-5993. doi:10.1016/j.tetlet.2013.08.059

11. Cogan, D. A.; Liu, G.; Kim, K.; Backes, B. J.; Ellman, J. A. J. Am. Chem. Soc. 1998, 120, 8011-8019. doi:10.1021/ja9809206

12. Robak, M. T.; Herbage, M. A.; Ellman, J. A. Chem. Rev. 2010, 110, 3600-3740. doi:10.1021/cr900382t

13. Arava, V. R.; Gorentla, L.; Dubey, P. K. Beilstein J. Org. Chem. 2012, 8, 1366-1373. doi:10.3762/bjoc.8.158

14. Borg, G.; Cogan, D. A.; Ellman, J. A. Tetrahedron Lett. 1999, 40, 6709-6712. doi:10.1016/S0040-4039(99)01351-9

15. Dave, A. M.; Patel, D. J.; Kumar, R.; Dwivedi, S. D. A process for preparing (+)-dapoxetine and its salts. WO Pat. Appl. WO2008035358A2, June 5, 2007.

\section{License and Terms}

This is an Open Access article under the terms of the Creative Commons Attribution License

(http://creativecommons.org/licenses/by/2.0), which permits unrestricted use, distribution, and reproduction in any medium, provided the original work is properly cited.

The license is subject to the Beilstein Journal of Organic Chemistry terms and conditions:

(http://www.beilstein-journals.org/bjoc)

The definitive version of this article is the electronic one which can be found at: $\underline{\text { doi: } 10.3762 / \text { bjoc. } 11.283}$ 